\title{
Academic Performance of Male versus Female Accounting Undergraduate Students: Evidence from Nigeria
}

\author{
Chinwuba Ambrose Okafor \\ Ph.D, Department of Accounting, Faculty of Management Sciences \\ University of Benin, Benin City, Nigeria \\ E-mail: chinwubao@yahoo.com \\ Osamuyimen Egbon (Corresponding author) \\ School of Management, University of St Andrews, The Gateway, North Haugh \\ St Andrews, KY16 9RJ, Scotland, United Kingdom \\ E-mail: egbonfcca@yahoo.co.uk
}

Received: March 8, 2011 Accepted: March 28, 2011 doi:10.5539/hes.v1n1p9

\begin{abstract}
Prior researches on the differences in classroom performance between male and female students show mixed results. While significant differences exist in some studies, others show no differences. Moreover, such studies were done in developed countries. This study aims to contribute to this gender discourse by using a developing country setting. It was hypothesized in this study that no differences exist between male and female performance in undergraduate accounting courses. The finding of this study reveals that there is no significant difference between academic performance of male and female accounting students in undergraduate accounting courses, although the males achieve a higher mean performance than their female counterpart in all the courses.
\end{abstract}

Keywords: Academic performance, Gender, Developing country, Nigeria

\section{Introduction}

There is an increasing interest in studying gender issue as it affects accounting education. As noted by Haynes (2008: 539):

The last two decades have witnessed an increase in literature applying concepts of gender or feminist perspectives to accounting. This special issue of Accounting, Auditing \& Accountability Journal and previous special editions of major journals (Accounting, Organizations and Society, 1987, Vol. 12 (1); Accounting, Auditing \& Accountability Journal, 1992, Vol. 5 (3); Accounting, Organizations and Society, 1992, Vol. 17 (3/4) and Critical Perspectives on Accounting, 1998, Vol. 9 (3)) demonstrate continuing interest in the subject.

In recent times a sea of literature has also emerged on the performance of university accounting students with emphasis on gender dimension. It is, however, interesting that empirical results on this issue have not been consistent. Whilst some studies reveal that female students outperform their male counterparts, others reveal the opposite. Still, others show no significant differences. Gender studies are gaining popularity across different disciplines and accounting cannot afford to be left out as such studies will tend to likely have implications for future teaching methods, curriculum enrichment and redesign, among others.

This study intends to contribute to this gender discourse in accounting by showing evidence from a developing country as previous studies tend to focus on the developed countries of America and Europe. Accounting has been traditionally viewed as a male-dominated profession with few female entrants, but recent studies show there is an increasing influx of females into accounting profession (Broadbent 1998, Hines 1992, Komori 2008, Worthington \& Higgs, 2001). This may be due in part to the fact that there is likely no significant difference between male and female in academic performance in accounting.

The study compares the performance of male and female students in introductory financial accounting courses in first year undergraduate programme for two academic sessions. This empirical study is intended to add to the 
building block of understanding gender performance in accounting education. Williams (1991:12) asserts that: 'Researching gender performance is like building a wall. No single study provides the whole wall - just one of the bricks.' Our emphasis, however, is to add a developing country block to such a multifaceted edifice.

\section{Literature Review}

Studies on gender dimension to academic performance of students are increasingly featuring across disciplines. Deepak et al.'s (2011) study shows that female medical students outperform male students in overall test assessment. Although Deepak et al.'s study suggests an evidence of male dominance in enrolment proportion, but female students were dominant in performance. Similar evidence of female students outperforming male students was also found in the field of agricultural science (Hedjazi and Omidi, 2008). These evidences do suggest that females are not intellectually dwarf and are likely to encourage more female enrolling on courses that have over time enjoyed masculine dominance.

Influx of females into accounting discipline in recent times has increased the number of females seeking accounting education in colleges and universities (Williams 1991). Williams' study focuses on whether differences exist between male and female classroom performance. However, the work was not an empirical paper but a review of findings of previous studies on this topic which highlighted existence of mixed results. Findings from many gender-based studies reveal that female students outperformed their male counterparts (Fraser et al. 1978, Mutchler et al. 1987, Bayes \& Nash, 1989). But only studies by Mutchler et al. (1987) and Bayes \& Nash (1989) show statistical significance. However, the studies by Lipe (1989), Tyson (1989) and Canlar \& Bristol (1988) show no differences in gender performance. Recently, Sheard (2009) finds that female students outperform their male counterparts and show more commitment and control over challenges they face during their study. One importance of Sheard's study is that it monitors the students' performance and progress from first year to the final year to track trend.

Empirical facts reveal that males have not dominated their female counterparts in performance over time in a profession that had hitherto been assumed as male-oriented. This might in part be inextricably linked to the reason why more females are increasingly entering the profession. Further studies may be required in this regard if the performance of females in the profession is a motivating factor surging further female enrollment in accounting. Evidence exists that female enrollment and pass rate have been surging even at the professional body level. Broadbent \& Kirkham (2008) highlight some trend in growth in female accountancy membership and studentship as follows: (insert table 1).

Table 1 reveals that female membership of some recognized accountancy bodies is not insignificant. Moreover, the size of female studentship of these bodies is also a pointer to a future growth in membership because the percentage of female students is consistently higher than that of female members for all the professional bodies specified above. And this potential growth portends gender neutrality for accounting profession in no distant future. This development is not exceptionally different from what obtains in Nigeria both in terms of females seeking training in professional accounting institutions and universities (including polytechnics).

\subsection{The Nigerian Admission Experience and Gender Performance}

Unlike what obtains in Western countries where prospective students apply directly to the universities and colleges of their choice, applicants in Nigeria apply through a central body called Joint Admissions and Matriculations Board. The Board is saddled with the responsibilities of conducting universities' entrance examinations for all prospective undergraduate students. JAMB started administering admissions' examinations (Universities Matriculations Examinations - UME) since 1978.

The legal instrument establishing the Board was promulgated by the Act (No. 2 of 1978) of the Federal Military Government on 13th February, 1978. By August 1988, the Federal Executive Council amended Decree No. 2 of 1978. The amendments have since been codified into Decree No. 33 of 1989, which took effect from 7th December, 1989.

Prospective students apply to JAMB with an opportunity to choose at most two programmes of study and Universities. Each university sets its JAMB admission score on a competitive basis, which makes such cut-off point to vary from one university to another. Upon universities granting admission to applicants, JAMB reserves the right to issue admission letters to the students.

One major breakthrough of JAMB is that of removing the hitherto burden on applicants of having to apply to different schools at different costs. Moreover, it saves some universities (especially the State Universities) from shortfall of students who might receive multiple admissions from both State and Federal Universities as such 
students would prefer the latter because they are cheaper and better funded. Over time, as the Universities became dissatisfied with JAMB examinations because it was riddled with high level of malpractices, they clamoured for internally conducted entrance examinations. Since JAMB examination was by government regulation, universities could not decline it but sought an additional entrance called Post Universities Matriculations Examination (PUME). PUME kicked off in 2004/2005 academic session in most Nigerian Universities, of which University of Benin was a pioneer. Those who satisfied a minimum level of performance in JAMB's UME are eligible to register for PUME. So the final admission is based on the performance in PUME. Still, JAMB reserves the right to issue admission letters to successful candidates.

From the foregoing, it becomes evident that academic performance determines gaining admission into any course of studies in Nigerian State and Federal Universities. Evidence from the University of Benin, Nigeria, reveals that female and male studentship in accounting is gender competitive. Data obtained from Senate approved results for four academic sessions were used as a proxy for number of students admitted as first year entrants for same periods. (insert table 2)

It could be observed from the above table that the number of female entrants competes favourably with that of the male entrants. This also corroborates the level of performance of females in relations to males because academic performance is a major admission criterion. In a rider to crystallizing performance of female vis-à-vis male accounting students, effort is made in this study to look beyond entrance examination performance as some students are given some measure of advantage over others if they are staff children, or are from a given catchment area or educationally less-developed areas, although they must satisfy some minimum level of performance. These other factors given consideration in admission criteria tend to bias the sanctity of admission through JAMB and PUME into Government Universities. In order to insulate these other factors that are not performance-based, emphasis is made in this study to focus on academic performance after admission.

As could be gleaned from Table 2, female enrolment is marginally different from that of male. This is somewhat very significant not only because accounting has been enjoying male-dominance, but also because Nigerian cultural belief $s$ that the place of the woman is in the kitchen. But whether this growth in enrolment, and probably academic performance, of female translate into career/professional progression is not contemplated within this paper. But this might merit future study given the age-long cultural bias against women and the recent rise in female enrolment in accounting. Bolton and Muzio (2008) and Berry (2007) show evidence of male dominance in professional career progression in spite of the increase in female membership of some professions. But Powell (1990) suggests that: "if there were no basic differences between male and female managers, it would be just a matter of time until the proportion of women was about the same as all managerial levels "(pp. 68-69). Intuitively, this might encourage persistent increase in female entry into the profession despite the imbalance in gender career progression.

\section{Research Method}

The subjects for this research are first year male and female accounting undergraduate students of the University of Benin, Nigeria, who sat for Introductory Financial Accounting courses namely, Introduction to Financial Accounting I \& II in 2004/2005 to 2007/2008 academic session. Reason for using these two semester courses is because there is the tendency that every student irrespective of sex and other factors will take the examinations with a high degree of seriousness. Given peculiar environmental factor, the use of an otherwise method to ascertain the performance level of students may be seriously biased arising from our understanding over time that many students perceive examination as their priority over any other form of assessments whether or not they constitute part of continuous assessment.

Since emphasis is on two introductory accounting courses, it is not possible to make use of grade point average (GPA), hence the utilization of grade performance. The University's grading system is as follows: seventy and above (A), sixty to sixty nine (B), fifty to fifty nine (C), forty five to forty nine (D), forty to forty four (E) and zero to thirty nine $(\mathrm{F})$ with a weight of five, four, three, two, one and zero respectively. This grading principle is also adopted for this study, and where a student gets absent $(\mathrm{AB})$ in the courses, such a student is removed from the sample in order not to bias the result as absent might not eventually crystallize as F (or zero). Tables in appendix A show a breakdown of the samples and their scores.

A statistical test of difference in two means is adopted. The T-test for testing difference in means of two samples reveals if there exists any difference between two independent samples. This test statistic is chosen for this study because the two groups of subjects are independent, which is an assumption that underlies its use. As the sample 
size is greater than thirty, it is assumed that the sample means approximate to the population means, hence Z-test variant of the T-test applies.

\subsection{Hypothesis}

$\mathrm{H}_{\mathrm{o}}$ : There is no difference between male and female students' academic performance in accounting.

\subsection{Limitation of This Study}

This study does not look at gender performance in higher level courses. There might be a different result if higher level courses are examined. Only accounting courses are considered in the study. And it is undeniable that prospective accountants require training in other subject areas like management, marketing, communication, IT, human resources, and so on, because they require skills more than number-crunching (French \& Coppage 2000; Usoff \& Feldmann 1998). However, the use of only introductory does not undermine the objective of this study, but future research could attempt a larger scale study to include higher level courses and all other subjects taken by accounting students.

\section{Discussion of Results}

Appendix B Tables B1 to B8 (except Table B3) show that there is no significant difference between the performance of male and female students in all introductory financial accounting courses for this study, even though the mean performance of male students was greater that of females for all the courses. Table B3 reveals that significant statistical difference exists between performance of male and female students but at $5 \%$ significant level. Same set of students had no statistical difference in the second semester course as in Table B4, which also holds true in 7 out of the 8 semesters tested, albeit covering students of different academic sessions. So the null hypothesis, which states that there is no difference between male and female students' academic performance in accounting, is accepted. The results presented above were tested at $5 \%$ level of significance. Moreover, no difference was still found when the data were also tested at $10 \%$ and $1 \%$ levels of significance. This finding conflicts with, and also consistent with, some earlier studies as shown in the literature review. The reason why female performance tends to compare favourably with that of male in Nigeria may not be unconnected with the current awareness by women that good education would give them access to job opportunities that will earn them respect among men. Until recently in Nigeria, it was religiously believed that the place of the woman is the kitchen, although some ardent traditionalists still hold such belief. If women are to gain recognition in this kind of society, and in a specific discipline hitherto dominated by men, they might have to strive for outstanding performance.

\section{Conclusion}

Results from this study show that there is no difference in academic performance between male and female undergraduate students. This outcome tends to add to the mixed results from previous studies. Our result is consistent with some previous studies (Lipe 1989, Tyson 1989 and Canlar \& Bristol 1988) and contrasts some others (Mutchler et al. 1987 and Bayes \& Nash 1989). The uniqueness of this study lies in its focus on a developing nation while previous studies had focused on the developed countries of the West. It thus enriches the discourse of male-female performance comparison by providing opportunity to compare results from developed and developing countries divide.

As implied by this study, males do not have significant dominance in academic performance over females in a profession that hitherto enjoyed male dominance. While females should be encouraged to enroll on accounting programmes, gender neutrality should be incorporated as a part of taught ethics in accounting so as to surge females' academic and accounting job performances especially in settings where females are culturally undermined by males.

However, caveat should be exercised in generalizing the findings from this study as the underlying samples are from one university. This does not undermine the finding of this study as Williams (1991) indentifies similar limitation in her study. Further researches that will incorporate more universities and likely more courses relevant to accounting discipline are encouraged so as to enrich this ongoing discourse. Another area of research interest could be gender motivation to the study of accounting, and whether or not it has implications for performance.

\section{References}

Berry, M. (2007). Number of Female Managers in FTSE 350 Companies Falls by 40 Per Cent in Five Years. Personnel Today, 8 March, p.11

Bolton, S. \& Muzio, D. (2008). The Paradoxical Processes of Feminization in the Professions: The Case of Established, Aspiring and Semi-professions. Work, Employment \& Society, 22(2), 281-299 
Broadbent, J. (1998). The Gendered Nature of 'Accounting Logic': Pointers to an Accounting that Encompasses Multiple Values. Critical Perspectives in Accounting, 9(3), 267-297

Broadbent, J. and Kirkham, L. (2008). Glass Ceiling, Glass Cliffs or New Worlds? Revisiting Gender and Accounting. Accounting, Auditing and Accountability Journal, 21 (4), 465-473

Canler, M. and Bristol, J. T. (1988). Female and Male Undergraduate Accounting Students: An Investigation of Academic Performance in Upper-Level College Accounting Courses. The Woman CPA, 50(2), 20-23

Deepak, K. K., Al-Umran, K. U., Al-Sheikh, M. H. \& Al-Rubaish, A. (2011). The influence of gender on undergraduate performance in multiple choice testing in clinical disciplines at University of Dammam, Saudi Arabia. Al Ameen Journal of Medical Science, 4(2), 123-130

French, G. R. and Coppage, R. E. (2000). Education Issues Challenging the Future of Accounting Profession. Ohio CPA Journal, 59(3), 69-73

Hedjazi, Y. \& Omidi, M. (2008). Factors affecting the academic success of agricultural students at University of Tehran, Iran. Journal of Agricultural Science and Technology. 10(3), 205-214

Hines, R. (1992). Accounting: Filling the Negative Space. Accounting, Organization and Society, 17(3/4), 313-341

Jackling B. and Calero, C. (2006). Influences on Undergraduate Students' Intentions to become Qualified Accountants: Evidence from Australia. Accounting Education: An International Journal, 15(4), 419-438

Federal Government of Nigeria (1989) JAMB Decree. [Online] Available: http://www.jambng.com/decree.php (June 18, 2010)

Komori, N. (2008). Towards the Feminization of Accounting Practice: Lessons from the Experiences of Japanese Women in the Accounting Profession. Accounting, Auditing and Accountability Journal, 21(4), 507-538

Lipe, M.G. (1989). Further Evidence on the Performance of Female Versus Male Accounting Students. Issues in Accounting Education, Spring, 144-152

Mutchler, J. F., Turner, J. H., and Williams, D. D. (1987). The Performance of Female Versus Male Accounting Students. Issues in Accounting Education, 12(1), 103-111

Powell, G. N. (1990). One More Time: Do Female and Male Managers Differ? Academy of Management Executive, 4(3), 68-75

Sheard, M. (2009). Hardiness, commitment, gender, and age differentiate university academic performance. British Journal of Educational Psychology, 79, 189-204

Tyson, T. (1989). Grade Performance in Introductory Accounting Courses: Why Female Students Outperform Males. Issues in Accounting Education, Spring, 153-160

Usoff, C. and Feldmann, D. (1998). Accounting Students' Perceptions of Important Skills for Career Success. Journal of Education for Business, 73(4), 215-220

Williams, L. K. (1991). A Synthesis of Research Studies on the Performance of Male and Female Accounting Students. The Woman CPA, 53(2), 12-15

Worthington, A. C. and Higgs, H. (2001). Australian Accounting Enrolments and Student Load: An Empirical Note on Trends and Composition through the 1990s. Accounting Research Journal, 14(2), 186-199

\section{Acknowledgement}

We wish to acknowledge the benevolence of the Department of Accounting, University of Benin, for granting us permission to use Senate approved results for our analysis. 
Table 1. Distribution of female professional accountancy membership and studentship

\begin{tabular}{|l|c|c|}
\hline Professional Institutions & Members & Students \\
\hline ACCA & $40 \%$ & $50 \%$ \\
\hline CIMA & $28 \%$ & $45 \%$ \\
\hline CIPFA & $27 \%$ & $*$ \\
\hline ICAEW & $23 \%$ & $40 \%$ \\
\hline ICA (Ireland) & $31 \%$ & $*$ \\
\hline ICA (Scotland) & $26 \%$ & $46 \%$ \\
\hline
\end{tabular}

* No percentage given

Source: Adapted from Broadbent \& Kirkham (2008:468)

Table 2. Proportions of male and female undergraduate students (University of Benin)

\begin{tabular}{|c|c|c|c|}
\hline Academic Year & Males & Females & Total (100\%) \\
\hline $2004 / 2005$ & $166(49.8 \%)$ & $167(50.2 \%)$ & 333 \\
\hline $2005 / 2006$ & $81(57.4 \%)$ & $60(42.6 \%)$ & 141 \\
\hline $2006 / 2007$ & $97(66 \%)$ & $50(34 \%)$ & 147 \\
\hline $2007 / 2008$ & $84(51.5 \%)$ & $79(48.5 \%)$ & 163 \\
\hline
\end{tabular}

Source: Adapted from Senate Approved Results for the four Sessions. 


\section{Appendix A}

Samples of male and female students' yearly academic performance for 2004/2005 to 2007/2008

Table A1. Samples and grades distribution for 2004/2005

\begin{tabular}{|c|c|c|c|c|}
\hline \multirow[b]{9}{*}{ 2004/2005 ACC111 } & Grades & Male & Female & Grade point \\
\hline & A & 15 & 10 & 5 \\
\hline & B & 23 & 21 & 4 \\
\hline & $\mathrm{C}$ & 36 & 44 & 3 \\
\hline & $\mathrm{D}$ & 13 & 12 & 2 \\
\hline & $\mathrm{E}$ & 45 & 55 & 1 \\
\hline & $\mathrm{F}$ & 20 & 19 & 0 \\
\hline & $\mathrm{AB}$ & 14 & 6 & \\
\hline & Total & 166 & 167 & \\
\hline \multirow[b]{9}{*}{ 2004/2005 ACC121 } & Grades & Male & Female & Grade point \\
\hline & $\mathrm{A}$ & 7 & 5 & 5 \\
\hline & B & 21 & 16 & 4 \\
\hline & $\bar{C}$ & 52 & 48 & 3 \\
\hline & $\mathrm{D}$ & 22 & 30 & 2 \\
\hline & $\mathrm{E}$ & 53 & 59 & 1 \\
\hline & $\mathrm{F}$ & 6 & 3 & 0 \\
\hline & $\mathrm{AB}$ & 5 & 6 & \\
\hline & Total & 166 & 167 & \\
\hline
\end{tabular}

Table A2. Samples and grades distribution for 2005/2006

\begin{tabular}{|c|c|c|c|c|}
\hline \multirow{10}{*}{} & Grades & Male & Female & Grade point \\
\cline { 2 - 5 } & $\mathrm{A}$ & 29 & 18 & 5 \\
\cline { 2 - 5 } & $\mathrm{B}$ & 36 & 21 & 4 \\
\cline { 2 - 5 } & $\mathrm{C}$ & 7 & 9 & 3 \\
\cline { 2 - 5 } & $\mathrm{D}$ & 4 & 3 & 2 \\
\cline { 2 - 5 } & $\mathrm{E}$ & 2 & 6 & 1 \\
\cline { 2 - 5 } & $\mathrm{F}$ & 2 & 3 & 0 \\
\cline { 2 - 5 } & $\mathrm{AB}$ & 1 & & \\
\hline & Total & 81 & 60 & \\
\hline \multirow{5}{*}{ 2005/2006 ACC111 } & Grades & Male & Female & Grade point \\
\cline { 2 - 5 } & $\mathrm{A}$ & 3 & 1 & 5 \\
\cline { 2 - 5 } & $\mathrm{B}$ & 23 & 10 & 4 \\
\cline { 2 - 5 } & $\mathrm{C}$ & 34 & 31 & 3 \\
\cline { 2 - 5 } & $\mathrm{D}$ & 7 & 7 & 2 \\
\cline { 2 - 5 } & $\mathrm{E}$ & 7 & 8 & 1 \\
\cline { 2 - 5 } & $\mathrm{F}$ & 4 & 2 & 0 \\
\cline { 2 - 5 } & $\mathrm{AB}$ & 3 & 1 & \\
\cline { 2 - 5 } & Total & 81 & 60 & \\
\hline
\end{tabular}


Table A3. Samples and grades distribution for 2006/2007

\begin{tabular}{|c|c|c|c|c|}
\hline \multirow[b]{8}{*}{ 2006/2007 ACC111 } & Grades & Male & Female & Grade Point \\
\hline & A & 45 & 21 & 5 \\
\hline & B & 22 & 11 & 4 \\
\hline & $\mathrm{C}$ & 6 & 10 & 3 \\
\hline & $\mathrm{D}$ & 2 & 1 & 2 \\
\hline & $\mathrm{E}$ & 2 & 0 & 1 \\
\hline & $\mathrm{F}$ & 0 & 1 & 0 \\
\hline & Total & 77 & 44 & \\
\hline \multirow[b]{8}{*}{ 2006/2007 ACC121 } & Grades & Male & Female & Grade Point \\
\hline & A & 28 & 11 & 5 \\
\hline & B & 40 & 22 & 4 \\
\hline & $\mathrm{C}$ & 11 & 9 & 3 \\
\hline & $\mathrm{D}$ & 2 & 2 & 2 \\
\hline & $\mathrm{E}$ & 1 & 0 & 1 \\
\hline & $\mathrm{F}$ & 5 & 1 & 0 \\
\hline & Total & 87 & 45 & \\
\hline
\end{tabular}

Table A4. Samples and grades distribution for 2007/2008

\begin{tabular}{|c|c|c|c|c|}
\hline \multirow[b]{8}{*}{ 2007/2008 ACC111 } & Grades & Male & Female & Grade point \\
\hline & A & 41 & 25 & 5 \\
\hline & $\mathrm{B}$ & 30 & 35 & 4 \\
\hline & $\mathrm{C}$ & 11 & 15 & 3 \\
\hline & $\mathrm{D}$ & 1 & 4 & 2 \\
\hline & $\mathrm{E}$ & 1 & 1 & 1 \\
\hline & $\mathrm{F}$ & & 0 & 0 \\
\hline & Total & 84 & 79 & \\
\hline \multirow[b]{8}{*}{ 2007/2008 ACC121 } & Grades & Male & Female & Grade point \\
\hline & A & 18 & 12 & 5 \\
\hline & $\mathrm{B}$ & 17 & 19 & 4 \\
\hline & $\mathrm{C}$ & 27 & 25 & 3 \\
\hline & $\mathrm{D}$ & 8 & 13 & 2 \\
\hline & $\mathrm{E}$ & 14 & 10 & 1 \\
\hline & $\mathrm{F}$ & 0 & 0 & 0 \\
\hline & Total & 84 & 79 & \\
\hline
\end{tabular}


Appendix B

Table B1. ACC111 Test Result for 2004/2005 Session

\begin{tabular}{|c|c|c|}
\hline z-Test: Two Sample for Means & & \\
\hline & Male & Female \\
\hline Mean & 2.276315789 & 2.142857143 \\
\hline Known Variance & 2.49 & 2.16 \\
\hline Observations & 152 & 161 \\
\hline Hypothesized Mean Difference & 0 & \\
\hline $\mathrm{z}$ & 0.773134655 & \\
\hline $\mathrm{P}(\mathrm{Z}<=\mathrm{z})$ one-tail & 0.219721347 & \\
\hline $\mathrm{z}$ Critical one-tail & 1.644853627 & \\
\hline $\mathrm{P}(\mathrm{Z}<=\mathrm{z})$ two-tail & 0.439442693 & \\
\hline $\mathrm{z}$ Critical two-tail & 1.959963985 & \\
\hline & & \\
\hline
\end{tabular}

Table B2. ACC121 Test Result for 2004/2005 Session

\begin{tabular}{|c|c|c|}
\hline z-Test: Two Sample for Means & & \\
\hline & Male & Female \\
\hline Mean & 2.310559006 & 2.186335404 \\
\hline Known Variance & 1.63 & 1.39 \\
\hline Observations & 161 & 161 \\
\hline Hypothesized Mean Difference & 0 & \\
\hline $\mathrm{z}$ & 0.907013155 & \\
\hline $\mathrm{P}(\mathrm{Z}<=\mathrm{z})$ one-tail & 0.18219992 & \\
\hline $\mathrm{z}$ Critical one-tail & 1.644853627 & \\
\hline $\mathrm{P}(\mathrm{Z}<=\mathrm{z})$ two-tail & 0.36439984 & \\
\hline $\mathrm{z}$ Critical two-tail & 1.959963985 & \\
\hline
\end{tabular}

Table B3. ACC111 Test Result for 2005/2006 Session

\begin{tabular}{|c|c|c|}
\hline z-Test: Two Sample for Means & & \\
\hline & Male & Female \\
\hline Mean & 4 & 3.55 \\
\hline Known Variance & 1.29 & 2.18 \\
\hline Observations & 80 & 60 \\
\hline Hypothesized Mean Difference & 0 & \\
\hline $\mathrm{z}$ & 1.964740826 & \\
\hline $\mathrm{P}(\mathrm{Z}<=\mathrm{z})$ one-tail & $0.024722121 *$ & \\
\hline $\mathrm{z}$ Critical one-tail & 1.644853627 & \\
\hline $\mathrm{P}(\mathrm{Z}<=\mathrm{z})$ two-tail & $0.049444242 *$ & \\
\hline $\mathrm{z}$ Critical two-tail & 1.959963985 & \\
\hline
\end{tabular}

Critical at 5\% level of significance 
Table B4. ACC121 Test Result for 2005/2006 Session

\begin{tabular}{|c|c|c|}
\hline z-Test: Two Sample for Means & & \\
\hline & Male & Female \\
\hline Mean & 2.948717949 & 2.711864407 \\
\hline Known Variance & 1.37 & 1.14 \\
\hline Observations & 78 & 59 \\
\hline Hypothesized Mean Difference & 0 & \\
\hline $\mathrm{z}$ & 1.233241978 & \\
\hline $\mathrm{P}(\mathrm{Z}<=\mathrm{z})$ one-tail & 0.108742749 & \\
\hline $\mathrm{z}$ Critical one-tail & 1.644853627 & \\
\hline $\mathrm{P}(\mathrm{Z}<=\mathrm{z})$ two-tail & 0.217485498 & \\
\hline $\mathrm{z}$ Critical two-tail & 1.959963985 & \\
\hline & & \\
\hline
\end{tabular}

Table B5. ACC111 Test Result for 2006/2007 Session

\begin{tabular}{|c|c|c|}
\hline z-Test: Two Sample for Means & & \\
\hline & Male & Female \\
\hline Mean & 4.376623377 & 4.113636364 \\
\hline Known Variance & 1.17 & 0.87 \\
\hline Observations & 77 & 44 \\
\hline Hypothesized Mean Difference & 0 & \\
\hline $\mathrm{z}$ & 1.406377174 & \\
\hline $\mathrm{P}(\mathrm{Z}<=\mathrm{z})$ one-tail & 0.079806077 & \\
\hline $\mathrm{z}$ Critical one-tail & 1.644853627 & \\
\hline $\mathrm{P}(\mathrm{Z}<=\mathrm{z})$ two-tail & 0.159612155 & \\
\hline $\mathrm{z}$ Critical two-tail & 1.959963985 & \\
\hline
\end{tabular}

Table B6. ACC121 Test Result for 2006/2007 Session

\begin{tabular}{|c|c|c|}
\hline z-Test: Two Sample for Means & & \\
\hline & Male & Female \\
\hline Mean & 3.885057471 & 3.866666667 \\
\hline Known Variance & 1.57 & 0.98 \\
\hline Observations & 87 & 45 \\
\hline Hypothesized Mean Difference & 0 & \\
\hline $\mathrm{z}$ & 0.092157276 & \\
\hline $\mathrm{P}(\mathrm{Z}<=\mathrm{z})$ one-tail & 0.463286541 & \\
\hline $\mathrm{z}$ Critical one-tail & 1.644853627 & \\
\hline $\mathrm{P}(\mathrm{Z}<=\mathrm{z})$ two-tail & 0.926573083 & \\
\hline $\mathrm{z}$ Critical two-tail & 1.959963985 & \\
\hline
\end{tabular}


Table B7. ACC111 Test Result for 2007/2008 Session

\begin{tabular}{|c|c|c|}
\hline z-Test: Two Sample for Means & & \\
\hline & Male & Female \\
\hline Mean & 4.297619048 & 4.113924051 \\
\hline Known Variance & 0.69 & 0.95 \\
\hline Observations & 84 & 79 \\
\hline Hypothesized Mean Difference & 0 & \\
\hline $\mathrm{z}$ & 1.291208399 & \\
\hline $\mathrm{P}(\mathrm{Z}<=\mathrm{z})$ one-tail & 0.098315712 & \\
\hline $\mathrm{z}$ Critical one-tail & 1.644853627 & \\
\hline $\mathrm{P}(\mathrm{Z}<=\mathrm{z})$ two-tail & 0.196631423 & \\
\hline $\mathrm{z}$ Critical two-tail & 1.959963985 & \\
\hline
\end{tabular}

Table B8. ACC121 Test Result for 2007/2008 Session

\begin{tabular}{|c|c|c|}
\hline z-Test: Two Sample for Means & & Female \\
\hline Mean & Male & 3.126582278 \\
\hline Known Variance & 1.202380952 & 1.52 \\
\hline Observations & 84 & 79 \\
\hline Hypothesized Mean Difference & 0 & \\
\hline $\mathrm{z}$ & 0.375862887 & \\
\hline $\mathrm{P}(\mathrm{Z}<=\mathrm{z})$ one-tail & 0.353509416 & \\
\hline $\mathrm{P}(\mathrm{Z}<=\mathrm{z})$ two-tail & 1.644853627 & \\
\hline $\mathrm{z}$ Critical two-tail & 0.707018832 & \\
\hline
\end{tabular}

